\title{
A SITUATED APPROACH TO ASSESS TEACHERS' PROFESSIONAL COMPETENCIES USING CLASSROOM VIDEOS
}

Jessica Hoth (Universität Vechta), Gabriele Kaiser (Universität Hamburg, Australian Catholic University), Martina Döhrmann (Universität Vechta), Johannes König (Universität zu Köln) \&

Sigrid Blömeke (Centre for Educational Measurement (CEMO), University of Oslo)

Teaching practice and its representation by videos are a central part of many empirical studies concerning the field of teaching and learning. In order to analyze how videos can help to investigate aspects of teachers' expertise, the data from 131 primary mathematics teachers who participated in the video-based study TEDS-Follow-Up were evaluated. The teachers answered questions referring to scripted video-clips describing classroom situations, the questions were qualitatively analyzed covering the spectrum of aspects mentioned by the teachers and its relation to aspects of teachers' expertise. The analyses showed that teachers notice and mention a great number of aspects that were either directly observable in the video-clip shown or could be identified using the given information. In addition, it is pointed out that teachers with high knowledge notice possible reasons for a student's error more accurately while teachers with low knowledge focus on aspects that are not directly connected to the student's learning.

\section{INTRODUCTION}

Research about teachers' expertise and teachers' competencies used a variety of approaches to gather information about the multifaceted abilities and skills that teachers require for their teaching profession. In addition to large-scale assessments that tested teachers' knowledge and beliefs by paper-and-pencil tests (e.g., Cognitively Activating Instruction and Development of Students' Mathematical Literacy (COACTIV), Kunter, Baumert, Blum, Klusmann, Krauss \& Neubrand 2011; Teacher Education and Development Study in Mathematics (TEDS-M), Blömeke, Hsieh, Kaiser \& Schmidt 2014; and Mathematics Teaching in the 21st century (MT21), Schmidt, Blömeke \& Tatto 2011), research approaches used representations close to real classroom practice in order to assess teachers' professional competences using videos (e.g., Kersting 2008, Kersting, Givvin, Sotelo \& Stigler 2010, Kersting, Givvin, Thompson, Santagata \& Stigler 2012; Star, Lynch \& Perova 2011; Kaiser, Busse, Hoth, König \& Blömeke 2015), text-vignettes (e.g., Dreher \& Kuntze 2015) or comic scenes (e.g., Herbst, Chazan, Kosko, Dimmel \& Erickson 2015). In connection with these approaches, the theoretical bases of these studies often also included more situation-specific facets of teachers' professional competencies. In order to analyze how video as a tool for representing teaching practice can help to investigate aspects of teachers' expertise, this paper presents a qualitative approach to analyze teachers' noticing of a video episode and links the results to their professional knowledge. In the following, the theoretical basis concerning teachers' expertise and teachers' professional competencies will be described. Subsequently, the methodological approach of a qualitative analysis of one selected question of the TEDS-FU video instrument will be presented as well as the results of this analysis.

\section{THEORETICAL BACKGROUND}

\subsection{TEACHERS' EXPERTISE AND TEACHER NOTICING}

In order to identify characteristics of expert teachers, research in the field of teachers' expertise usually contrasted experts and novice teachers (Berliner 2001). In this regard, expert and novice 
teachers differed with regard to their situation-specific skills that become relevant in the course of teaching. The three situation-specific facets - the perception, interpretation and decision-making during class - were prominent facets concerning the concept of teachers' noticing (Sherin, Jacobs \& Philipp 2011a, Jacobs, Lamb \& Philipp 2010) and also were central components of teachers' professional competencies as they were conceptualized and assessed in some studies as the TEDSFollow-Up study (see section 4.1, Kaiser et al. 2015).

Research showed that expert and novice teachers' perceptions differ with regard to identifying relevant aspects for children's learning. Expert teachers distinguish important and less important information while novice teachers more often perceive surface characteristics (Berliner 2001). In addition, novice teachers may more often focus on the teacher and aspects of classroom management than on the subject and the classroom discourse (Star \& Strickland 2008). „When issues of content were noticed, preservice teachers tended to comment only about whether the content was presented accurately and clearly and/or to provide a chronological description of what the teacher wrote on the board during the lesson" (ibid., p. 122).

These kinds of differences also became obvious comparing expert and novice teachers' interpretation of classroom situations. In this regard, Sherin, Jacobs \& Philipp (2011b, p. 5) pointed out that (teachers') perception and interpretation seem to be more "interrelated and cyclical". While novice teachers rather use descriptions of what happened in class, expert teachers interpret the situation deeply and precisely (Sabers, Cushing \& Berliner 1991, Carter, Cushing, Sabers, Stein \& Berliner 1988). Problems in student learning processes which are based on complex teaching situations may be identified faster by expert teachers while novices rather identify the error itself and, again, describe the error but do not interpret it (Chi, Feltovich \& Glaser 1981).

As another difference between expert and novice teachers could be identified that ,as a group, experts are much more interested in analyzing why things are happening instead of critically commenting on the fact that events have happened" (Sabers et al. 1991, p . 81). In her learning to notice framework, Van Es (2011) described different phases of teacher noticing development. Here, teacher noticing evolved with regard to what is noticed and how teachers notice. While teachers with baseline noticing may more often attend to the teacher and his or her pedagogy as well as students' behavior, teachers' noticing shifts in the subsequent stages to students' learning and the relationship between students' mathematical thinking and teaching strategies (ibid.). With regard to how teachers notice, baseline noticing is characterized by mentioning general aspects of what occurred as well as descriptive and evaluative comments. Then again, extended noticing as the most advanced stage of noticing includes identifying noteworthy events and providing interpretative comments that refer to specific events and interactions as evidence for what was noticed (ibid.).

In addition, expert and novice teachers seemed also to differ with regard to their decision-making. As Jacobs et al. (2010) analyzed - in addition to teachers' attending to and interpreting children's strategies - teachers decide on how to respond on the basis of children's understanding. They pointed out that the development of this specific facet can be characterized by various aspects such as "a shift from general comments about teaching and learning to comments specifically addressing the children's understandings; a shift from overgeneralizing children's understandings to carefully linking interpretations to specific details of the situation" (ibid, p. 196). 


\subsection{TEACHERS' PROFESSIONAL KNOWLEDGE AND ITS CONNECTION TO TEACHERS' NOTICING}

The differences between expert and novice teachers' perception, interpretation and decision-making processes - as described in the previous section - may have resulted from their different knowledge bases (Livingston \& Borko, 1989). Teachers' perceptions and interpretations were both assumed to be knowledge-based because teachers' knowledge guides their perceptions and provides the basis for their interpretations of the perceived instances (e.g., Schäfer \& Seidel 2015). Following the question of how teachers' noticing is linked to their professional knowledge, the definition of teacher noticing by Van Es and Sherin (2002, p. 573; Sherin 2010b) proposed an interrelation between perception, interpretation and knowledge. "We propose three key aspects of noticing:

(1) Identifying what is important or noteworthy about a classroom situation

(2) Making connections between the specifics of classroom interactions and the broader principles of teaching and learning they represent and

(3) Using what one knows about the context to reason about classroom interactions"

As Van Es and Sherin pointed out, teachers need to perceive important classroom situations and interpret them with regard to broader principles of teaching and learning using their professional knowledge. According to Shulman $(1986,1987)$, the main facets of teachers' professional knowledge are (1) content knowledge (in the case of mathematics teachers, this would be the mathematics content knowledge, short: MCK), their pedagogical content knowledge (MPCK) and their general pedagogical knowledge (GPK). "Thus, teachers must use their knowledge of the subject matter, knowledge of how students think of the subject matter, as well as knowledge of their local context to reason about events as they unfold" (Van Es \& Sherin 2002, p. 574 f.).

Linking teachers knowledge to their actual performance in the classroom, Blömeke, Gustafsson \& Shavelson (2015, see figure 1) proposed a model of competence as a continuum, and integrated the situation-specific skills perception, interpretation and decision-making into their model of competence as a mediator between disposition and performance. Therefore, knowledge was hypothesized underlying performance but the relation may be mediated by the situation-specific skills, "cobbled together in response to task demands, somewhat differently for each person" (ibid. p. 6).

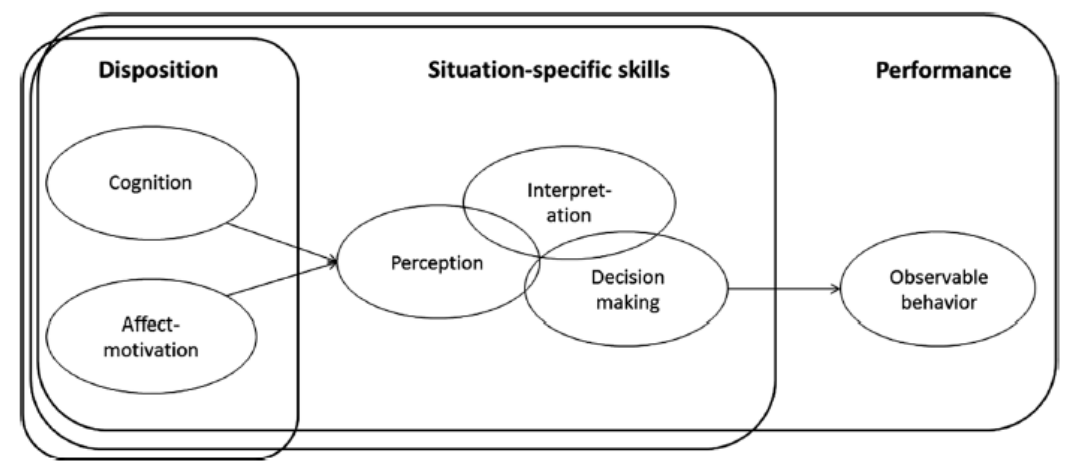

Figure 1: Modeling competence as a continuum (Blömeke et al. 2015, p. 7) 
Referring to the comparison of novice and expert teachers, it was assumed that expert teachers' use their knowledge more flexibly to interpret classroom incidences while this is more problematic for novice teachers (Berliner 2001). Kersting et al. (2008, 2010, 2012) found that teachers' mathematical content knowledge for teaching positively related to their ability to interpret classroom videos, concluding that "teachers used their pedagogical and mathematical content knowledge for teaching when analyzing classroom situations" (Kersting 2008, p. 14). Accordingly, König, Blömeke, Klein, Suhl, Busse \& Kaiser (2015) found that teachers' skill to interpret classroom incidents significantly correlates with their GPK while this connection was not found for teachers' skill to perceive specific classroom events and their GPK. With regard to comparing a video-based assessment of teachers' classroom management expertise and teachers' general pedagogical knowledge assessed by a paper-and-pencil test, König and Kramer (2016, p. 148) found that "teachers' general pedagogical knowledge and classroom management expertise are two different constructs, although they are substantially and positively inter-correlated."

However, Blomberg, Stürmer \& Seidel (2011) proposed - based on their findings - that professional vision is a generic ability but not necessarily subject-related, while Dreher \& Kuntze (2014, p. 110) found that "there is not a simple relationship between successful theme-specific noticing and a single component of professional knowledge. Instead, drawing on a variety of different components of professional knowledge and views can result in successful theme-specific noticing".

In this regard, Schäfer and Seidel (2015) pointed out that there is still only little research about the connection between teacher noticing and different knowledge facets. This was one of the main starting points for the following analyses that focused on mathematics teachers' noticing and its connection to their knowledge base.

\section{RESEARCH QUESTION}

Many of the empirical studies presented in the previous section used video as a tool for representing practice to analyze teachers' expertise and teachers' noticing (cf. Schäfer \& Seidel 2015, Kersting 2008, 2010, 2012, Blomberg et al. 2011, Van Es \& Sherin 2002). These videos had different functions in accordance with each of the respective study's research aim. For example, Van Es and Sherin (2002) used videos in teacher training (so-called video clubs) to discuss and reflect the teachers' practices with the group of participating teachers while Kersting (2008) used video to measure the quality of teachers' classroom analysis.

Following the aim to identify aspects that characterize how expert teachers notice classroom processes, the present study was based on data collected with a video test instrument and aimed at analyzing the research question:

How can video as a tool for representing teaching practice help to investigate aspects of teacher expertise, such as aspects of noticing (in this case: the subdimensions perception and interpretation)?

To answer this question, data collected with the video instrument of the TEDS-Follow-Up study was used, which will be described in the following section. Primary mathematics teachers' 
responses to a video sequence will be the focus of the following analyses and will be complemented by information about teachers' knowledge from another test part of the TEDS-Follow-Up study. The following section presents the methodological approach and describes the TEDS-Follow-Up study and its test instruments.

\section{METHODOLOGICAL APPROACH}

In order to utilize the potential that video offers to investigate aspects of teacher expertise, a qualitative approach was chosen using the data from the video-based test of the TEDS-Follow-Up study.

\subsection{THE TEDS-FOLLOW-UP STUDY}

TEDS-Follow-Up was the longitudinal Follow-Up to the international Teacher Education and Development Study in Mathematics (TEDS-M; e.g., Blömeke et al. 2014). TEDS-M was conducted under the auspices of the IEA (International Association for the Evaluation of Educational Achievement), and assessed the professional competence of future mathematics teachers at the end of their education in 16 participating countries. In Germany, about 2,000 preservice teachers participated in the study in 2008. A subset of these teachers was reassessed in 2012 in the TEDSFollow-Up study. 131 primary school teachers who had about 4 years of work experience took part in the study which was realized as an online assessment. Following the model of competence as a continuum (see figure 1) and widening the theoretical framework, the TEDS-Follow-Up study closely referred to work in the field of teachers' expertise (Li \& Kaiser 2011) and the concept of teacher noticing (Sherin et al. 2011a) and also included situation-specific skills as one main facet of teachers' competencies. More precisely, three situation-specific skills are considered:

“(a) Perceiving particular events in an instructional setting,

(b) Interpreting the perceived activities in the classroom

(c) Decision making, either as anticipating a response to students' activities or as proposing alternative instructional strategies" (Kaiser et al. 2015, p. 373) ${ }^{1}$.

The video test instrument of the TEDS-Follow-Up study consisted of three video clips with corresponding questions. In order to identify expert teachers in the sample of TEDS-Follow-Up, the knowledge scores that resulted from the online tests 1 and 2 were used to provide additional information. As discussed in section 2.2, teachers' noticing may be closely connected to their expertise. Figure 2 shows a short version of the design of the TEDS-Follow-Up study containing only the parts relevant for this paper.

\footnotetext{
${ }^{1}$ For a detailed description of the theoretical base and conceptualizations in the TEDS-M e.g., Blömeke et al. 2014; for the TEDS-Follow-Up study e.g., Hoth, Döhrmann, Kaiser, Busse, König \& Blömeke 2016, Kaiser et al. 2015).
} 


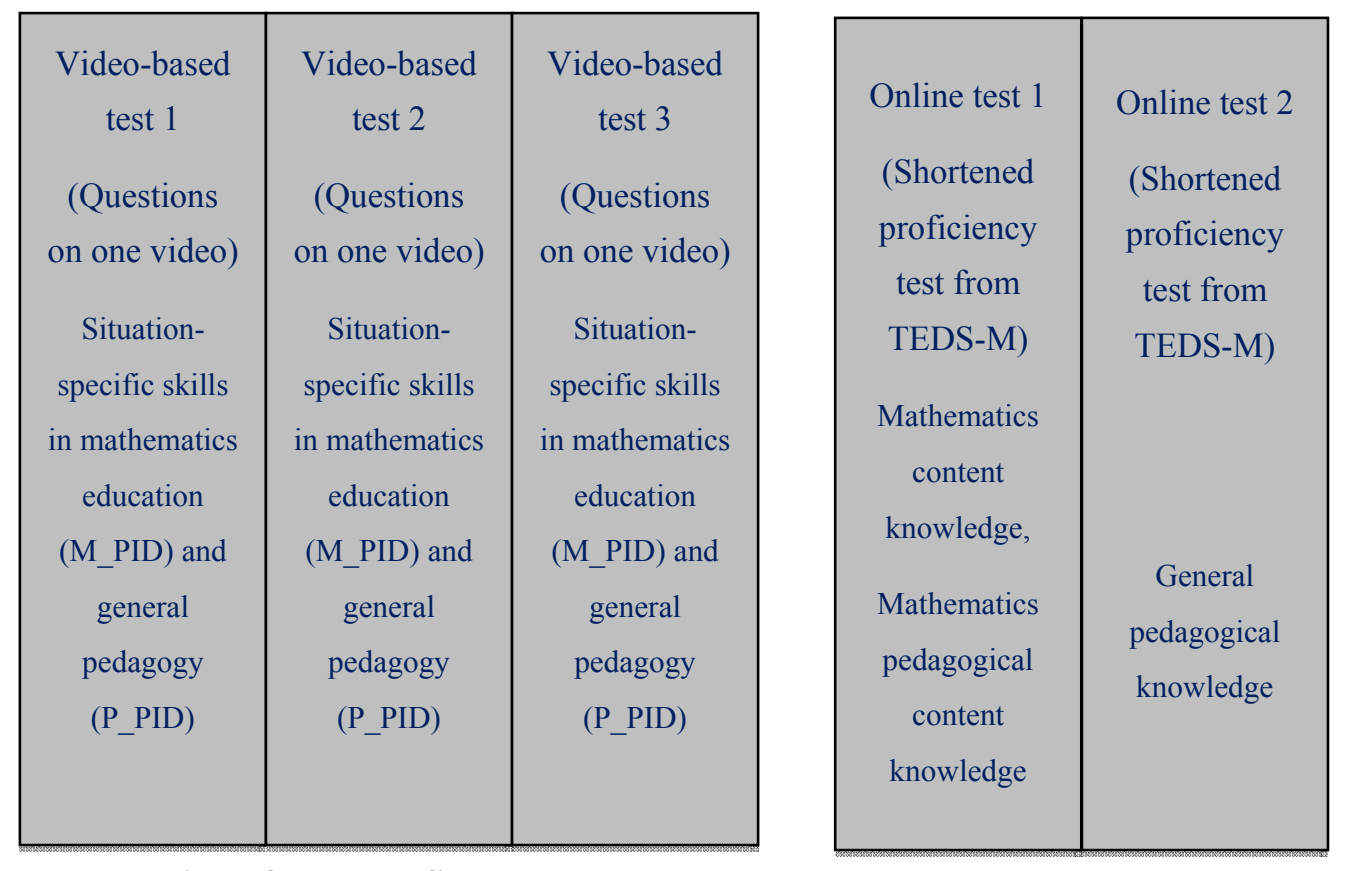

Figure 2: Shortened Design of the TEDS-Follow-Up study

The video-based tests were developed for the TEDS-Follow-Up study to assess the situationspecific skills perception, interpretation and decision-making. In the video-based tests, the study participants watched three short video clips (three to five minutes) showing excerpts of mathematics classes, and were asked to answer corresponding questions afterwards. The questions were presented in closed and open formats, and referred to didactical and pedagogical aspects of the teaching episode. The videos itself were scripted classroom scenes including cuts. Each of the videos had a different mathematical topic and showed classes in different instructional phases. Concerning the videos of the primary school study, all of the three video clips presented third-grade mathematics classes. One video dealt with geometry as mathematical content while the instructional phases in this video were the introduction of the mathematical content by the teacher as well as part of the working phase of the children. Another video showed a mathematics class searching and discussing patterns and structures in Pascal's triangle. This video started during the working phase and included the beginning of the final phase of the lesson where the students presented their results in a plenary session. The third video dealt with third-grade learners working on a real-life mathematics task. The video showed the introductory phase of the lesson as well as the accompanying group work of the students subsequent to the introductory phase.

The participating teachers were provided with background information about the mathematical content of the lesson, additional information about the class and their learning conditions as well as information about what happened in former lessons. The teachers were always able to re-access this information when they answered the test questions subsequent to watching the video. In order to be as close to real teaching situations as possible, the teachers were only able to watch the videos once without the option to pause, rewind or fast-forward. 


\subsection{DATA SAMPLING AND DATA ANALYSIS}

In order to illustrate how representations of classroom practice can help to investigate aspects of teacher expertise, we selected one question of the video vignette Geometry that required the teachers to notice crucial aspects with regard to children's learning in the teaching episode presented in the video. More precisely, the question focuses on those aspects of the teaching sequence that basically led to a student's errors (as described below). Therefore, all information which is given within the complex and multifaceted teaching sequence became relevant and had to be interpreted with regard to the student's understanding as shown in the video. In the following, the video vignette Geometry is described in more detail as well as the selected question.

The video shows the beginning of a geometry lesson about Pentominoes ${ }^{2}$ in a third-grade mathematics classroom. The students and the teacher sit in a circle of chairs while the teacher introduces these special geometric figures. She explains to the students how Pentominoes are built, presents their names and also mentions the concept of congruence to the children. Thereby, she shows one Pentomino example to the children (all squares are arranged in one row; see figure 3) by placing five squares in the middle of the circle. She also provides a poster that lists the building criteria of Pentominoes and shows some examples (see figure 4); she does not give an example for congruent Pentominoes but puts up a poster that verbally covers all aspects of congruence on an abstract level. The teacher then presents the task to the children who are asked to find all existing Pentominoes and justify the number of varying figures. As assisting materials, the teacher provides little squares that each student can use individually to build their Pentominoes. After building them, the students are also asked to draw a representation of the Pentomino into their notebooks. Finally, the children get the chance to ask questions about the content presented as well as the given task.

In the following, the video shows one girl who presents her solution to the teacher. She explains that there must be 10 Pentominoes because she has 10 options to place the 5th square (see figure 5). In the following, the girl also provides an idea to prove her statement.

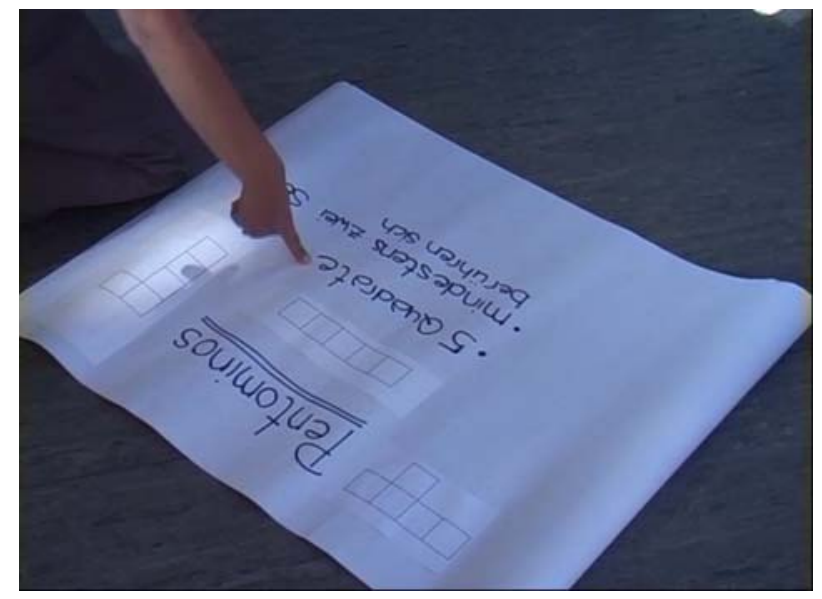

Figure 3: Poster

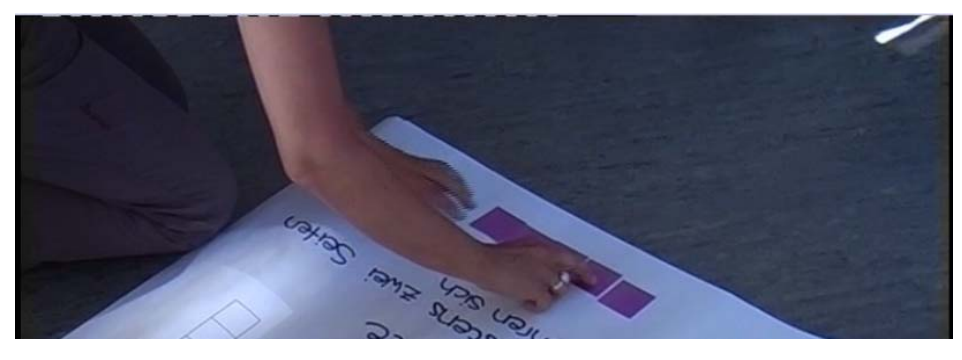

Figure 4: Teacher example

\footnotetext{
${ }^{2}$ Pentominoes are plane geometric figures that consist of five squares. Each of those squares most be connected to at least one other square with one side. Figures with four squares are called Tetrominos etc. For more information about Pentominoes see Golomb 1994.
} 

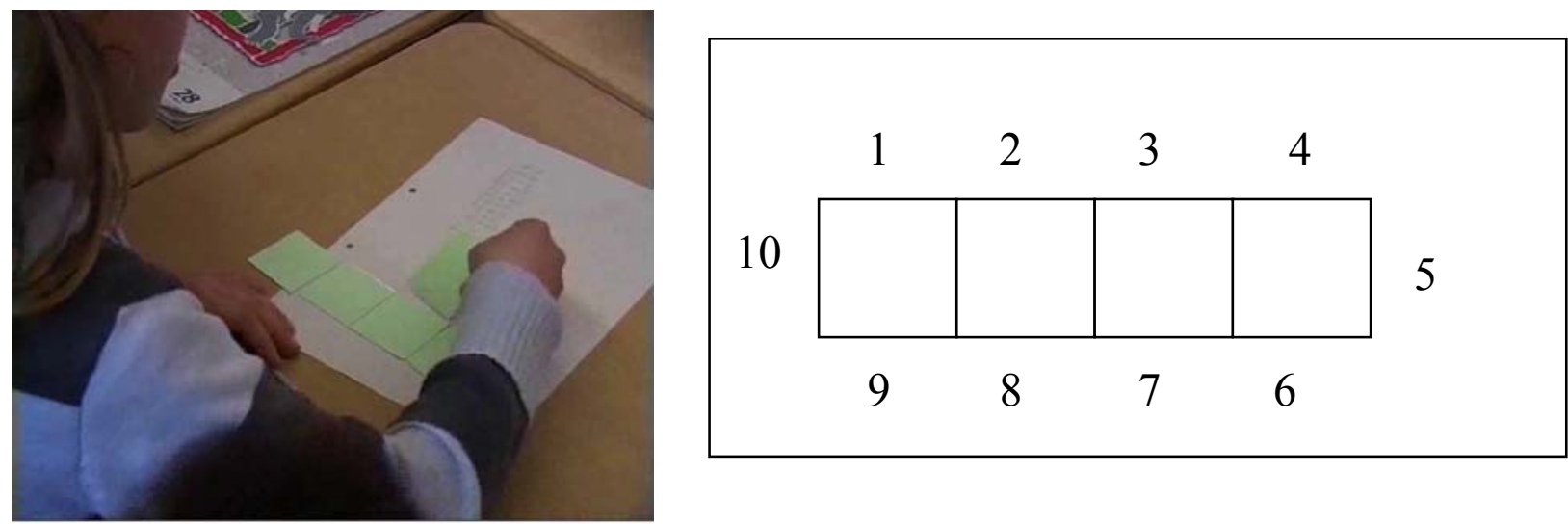

Figure 5: Student's solution in the video-vignette "Geometry"

However, she also makes two mistakes in her solution process. First, she finds Pentominoes only on the basis of one specific Tetromino and, second, she does not consider congruency. The question that was selected for the analyses in this paper draws on these mistakes and asks the teachers to analyze the teaching sequence that they saw in the video-vignette with regard to the student's errors. The teachers were asked to identify three instances in the course of the teaching process shown that may have caused the student's errors (the errors itself were named in the question: not considering congruency and identifying Pentominoes only on the basis of one specific Tetromino). The teachers were given three open response fields.

This specific question was chosen for the following analyses because those aspects typical for expert teachers' perception and interpretation can be revealed through this complex question that requires the teachers to evaluate all the information they gathered in the course of watching the video. In the TEDS-Follow-Up study, teachers' answers were coded based on an extensive coding manual, which was based on in-vivo-codes developed out of the test persons answers and extensive expert ratings. For each question, $20 \%$ of the data was coded by two persons individually - interrater reliability resulting to $\kappa \approx 0.74$. In addition, expert ratings were realized in order to evaluate content-validity (for details on the approach referring to the rating-scale items see Hoth, Schwarz, Kaiser, Busse, König \& Blömeke, 2016).

Referring to the selected question, answers were coded as 'correct' if they presented instances that actually happened in the video. In addition, they had to refer to the student's errors and had to either explain her disregarding congruency or finding Pentominoes only on the basis of one Tetromino. These requirements applied to five instances: (1) The teacher directly started with Pentominos, excluding preceding figures such as Tetrominoes, Triominoes etc. (2) the teacher presents one Pentomino example that also consists of that specific Tetromino, (3) the Pentomino examples on the poster were all build on the basis of that Tetromino, (4) the student did not understand the concept of congruency and (5) the didactic material which the teacher offered to find Pentominoes did not allow the students to flip and rotate their figures.

The data for the analyses were the answers of the 131 primary mathematics teachers who participated in the TEDS-Follow-Up study. As evaluation method, qualitative text analysis (cf. Mayring 2015, Kuckartz 2014) was used. Here, reducing processes (Mayring 2015) were used to analyze the many facets of the teachers' answers to the selected question. "The object of the analysis [using reducing processes] is to reduce the material such that the essential contents remain, 
in order to create through abstraction a comprehensive overview of the base material which is nevertheless still an image of it“" (ibid, p.373). Thus, the summarizing categories represent every aspect that the teachers mentioned with regard to the selected question and built the basis for analyzing aspects of teachers' expertise. Each category could be classified as more or less significant for explaining the student's errors and, therefore, provided information about the teachers' expertise. In this context, meaningful was related to the preciseness of teachers interpreting the classroom incidents with regard to the student's error. In addition, frequency analyses (cf. ibid.) gave insight into the distribution and emphasis of teachers' answers. The results of this inductive coding process as well as example answers for each of the resulting categories are presented in table 1 .

The qualitative results were then related to the scores from the standardized MCK, MPCK and GPK assessments. As in the TEDS-M study, the international average for these scores was set to 500 with a standard deviation of $100^{3}$. The subsample of German primary teachers who again participated in the Follow-Up study had an average of 531 concerning their MCK and MPCK and an average of 644 concerning their GPK. More precisely, for each of the qualitatively found categories, the mean value was determined of those teachers' knowledge scores who named that category. The mean differences were then analyzed using T-Tests in order to verify significant differences.

\section{RESULTS}

In the selected task, 17 categories were reconstructed inductively. This high amount of categories already shows the complexity and variance of teachers' answers (see table 1). In the following, the different categories are described and elaborated on by example answers of the participating teachers. The third column reports the number of occurrences of each respective category within the teachers' answers. Since the teachers were asked to name three aspects ${ }^{4}$ that may have caused the student's mistakes, teachers predominately named more than one aspect $[\min =0 ; \max =6]$. Therefore, one teacher may be counted into more than one category and the number of occurrences does not equal the number of teachers who participated in the study. Furthermore, the answer a teacher provided in one open-response field could include more than one aspect. This evaluation procedure along categories with variable teacher groups seemed to be adequate for the evaluation of the richness of the categories named.

\begin{tabular}{|c|c|c|}
\hline Category name and description & Example Answer ${ }^{5}$ & $\begin{array}{l}\text { Number of } \\
\text { occurrences }\end{array}$ \\
\hline $\begin{array}{l}\text { Incomprehension of congruence: The student's mistake } \\
\text { is based on her incomprehension of the concept of } \\
\text { congruence. }\end{array}$ & $\begin{array}{l}\text { "The children did not understand the } \\
\text { concept of congruency." } \\
\text { (Teacher1164) }\end{array}$ & 48 \\
\hline $\begin{array}{l}\text { Ensuring students' comprehension: The teacher in the } \\
\text { video did not ensure that the students understood the }\end{array}$ & $\begin{array}{l}\text { "The teacher did not check whether } \\
\text { the children actually understood }\end{array}$ & 22 \\
\hline
\end{tabular}

\footnotetext{
${ }^{3}$ For further details about the instruments and the scaling of the TEDS-M study see Tatto, Schwille, Senk, Ingvarson, Rowley, Peck, Bonkov, Rodriguez \& Reckase 2012

${ }^{4}$ There were three open response fields in the web-based test.

${ }^{5}$ A teacher's answer can include more than one aspect.
} 


\begin{tabular}{|c|c|c|}
\hline subject matter/the work assignment and so on. & everything.” (Teacher1050) & \\
\hline $\begin{array}{l}\text { The teacher's example in the introduction: The } \\
\text { student's mistake can be ascribed to the teacher presenting } \\
\text { only one example of a Pentomino which was based on } \\
\text { only one Tetromino in the introductory phase of the } \\
\text { lesson. }\end{array}$ & $\begin{array}{l}\text { "The teacher placed that example } \\
\text { which is based on that specific } \\
\text { Tetromino in front of the children." } \\
\text { (Teacher1090) }\end{array}$ & 48 \\
\hline $\begin{array}{l}\text { Missing student activities: Since the students did not } \\
\text { have the opportunity to find and explore the } \\
\text { Pentominoes/their structure/congruent figures, they did } \\
\text { not develop understanding. }\end{array}$ & $\begin{array}{l}\text { "The children should have worked } \\
\text { practically on congruency." } \\
\text { (Teacher1668) }\end{array}$ & 20 \\
\hline $\begin{array}{l}\text { More than five squares as working material: The } \\
\text { student's mistakes may have happened due to the fact that } \\
\text { the students had more than five squares available to work } \\
\text { with during the working phase of the lesson. }\end{array}$ & $\begin{array}{l}\text { "She has more than five squares to } \\
\text { work with." (Teacher1061) }\end{array}$ & 4 \\
\hline $\begin{array}{l}\text { The abstractness of teacher's description: The children } \\
\text { did not understand the lesson's subject matter because the } \\
\text { teacher's explanations were too abstract, involved too } \\
\text { many technical terms and/or mathematical inaccurate } \\
\text { facts. }\end{array}$ & $\begin{array}{l}\text { The teacher's explanation was too } \\
\text { specialized. The students did not } \\
\text { understand." (Teacher1294) }\end{array}$ & 49 \\
\hline $\begin{array}{l}\text { Missing motivation: The mistakes can be ascribed to } \\
\text { missing motivation on the side of the student or the } \\
\text { teacher failure to motivate her students. }\end{array}$ & “Missing motivation” (Teacher1063) & 3 \\
\hline $\begin{array}{l}\text { Missing clarification of preceding figures: The student } \\
\text { did not consider other Pentominoes because the teacher } \\
\text { and her instruction did not consider the preceding figures } \\
\text { such as Dominoes, Trominoes and Tetrominoes. }\end{array}$ & $\begin{array}{l}\text { "It would be possible to begin by } \\
\text { searching all the Tetrominos (in the } \\
\text { sitting circle)." (Teacher987) }\end{array}$ & 10 \\
\hline $\begin{array}{l}\text { Missing visual example and/or counterexample: The } \\
\text { teacher failed to present a visual example and/or } \\
\text { counterexample to the students that may have } \\
\text { strengthened their understanding. }\end{array}$ & $\begin{array}{l}\text { "The teacher did not show an } \\
\text { example of congruent Pentominoes." } \\
\text { (Teacher 1217) }\end{array}$ & 38 \\
\hline $\begin{array}{l}\text { Pentomino examples on the poster: The poster that the } \\
\text { teacher presents to the students about the building } \\
\text { structure of Pentominoes also only shows Pentominoes } \\
\text { that are based on the one Tetromino with all squares in } \\
\text { one row. }\end{array}$ & $\begin{array}{l}\text { "The examples on the poster also } \\
\text { show two Pentominoes made of that } \\
\text { Tetromino." (Teacher1729) }\end{array}$ & 11 \\
\hline $\begin{array}{l}\text { Missing response to students' questions: The teacher } \\
\text { did not respond (appropriately) to students' questions } \\
\text { which may have negative influence on their } \\
\text { understanding. In addition, she did not provide }\end{array}$ & $\begin{array}{l}\text { "The teacher did not react on } \\
\text { questions and suggestions of students } \\
\text { in the beginning of the lesson." } \\
\text { (Teacher1132) }\end{array}$ & 16 \\
\hline
\end{tabular}




\begin{tabular}{|c|c|c|}
\hline appropriate support such as strategic advice. & & \\
\hline $\begin{array}{l}\text { Manageability of didactic material: The material that } \\
\text { the teacher offers the students to work with does not } \\
\text { enable the students to flip and rotate their found } \\
\text { Pentominoes. Therefore, Karola is not able to consider } \\
\text { congruency. }\end{array}$ & $\begin{array}{l}\text { "How is the girl supposed to test } \\
\text { congruency if the Pentominoes that } \\
\text { she finds only consist of individual } \\
\text { components? This offers few } \\
\text { opportunities to try out." } \\
\text { (Teacher1278) }\end{array}$ & 6 \\
\hline $\begin{array}{l}\text { Color highlighting the Pentomino examples: The } \\
\text { Pentominoes that the teacher provided on her poster are } \\
\text { not optimally color highlighted. }\end{array}$ & $\begin{array}{l}\text { "All squares have the same color." } \\
\text { (Teacher1665) } \\
\text { "The alternatives on the poster are not } \\
\text { colored clearly enough." } \\
\text { (Teacher1209) }\end{array}$ & 4 \\
\hline $\begin{array}{l}\text { At least two sides are touching: The teacher explained } \\
\text { the building structure of Pentominoes in that each of the } \\
\text { five squares is touching at least one side of another } \\
\text { square. However, the children did not understand the } \\
\text { meaning of this statement. }\end{array}$ & $\begin{array}{l}\text { "Two sides of the squares have to be } \\
\text { touching." (Teacher1691) }\end{array}$ & 14 \\
\hline $\begin{array}{l}\text { Pentominoes consist of five squares: The children did } \\
\text { not know that the Pentominoes consist of five squares. }\end{array}$ & $\begin{array}{l}\text { "In Karola's solution, there are five } \\
\text { squares in a row. She keeps } \\
\text { positioning the sixth square to present } \\
\text { her solution. She did not understand } \\
\text { that a Pentomino consists of only five } \\
\text { squares." (Teacher 1671) }\end{array}$ & 4 \\
\hline $\begin{array}{l}\text { Pentominoes' name: The children did not understand the } \\
\text { term Pentomino as the name for the figures. }\end{array}$ & $\begin{array}{l}\text { "Karola does not know what } \\
\text { Pentominos are and how they are } \\
\text { build." (Teacher 1517) }\end{array}$ & 3 \\
\hline $\begin{array}{l}\text { Lack of student-to-student interaction: The mistakes } \\
\text { may have occurred due to the lack of student-to-student } \\
\text { interaction. }\end{array}$ & $\begin{array}{l}\text { "There was no group work or a } \\
\text { possibility for the students to } \\
\text { communicate with each other." } \\
\text { (Teacher1433) }\end{array}$ & 5 \\
\hline $\begin{array}{l}\text { Answer does not refer to the question: This category } \\
\text { subsumes all teachers' answers that do not correctly refer } \\
\text { to the given question }\end{array}$ & $\begin{array}{l}\text { "She uses the wrong equation." } \\
\text { (Teacher979) }\end{array}$ & 15 \\
\hline
\end{tabular}

Table 1: Category results of the inductive coding, Teachers' example answers and frequency analysis ${ }^{6}$

\footnotetext{
$650 \%$ of the data was coded by two researchers independently. Interrater- reliability was satisfactory with Kappa $=.808$
} 
This analysis shows that the same video sequence and this one specific question provide the basis for different and multifaceted teacher answers. Obviously, teachers perceive different aspects in the same situation and with the same question as the starting point for their analyses, and their answers differ in regard to the aspects perceived. Some of the categories refer more closely to the student's errors and a possible explanation for the errors while others do not.

In order to understand the complexity of these categories as well as the approach that teachers used to perceive and interpret the information in the video, the categories are analyzed with regard to their appearance in the video in the following analysis. Some of the aspects mentioned by the teachers are directly observable in the video (have observable evidence in the video) while others are results of interpreting processes. This analysis, therefore, closely refers to the idea of evidencebased analysis (Van Es \& Sherin 2002). For example, the category "Pentomino examples on the poster" directly refers to visual objects within the video - namely the Pentominoes which the teacher placed on her poster. However, within the video sequence, the teacher does not address these figures directly, they only appear on the poster but are not addressed by any actor in the video. Therefore, teachers who perceive these figures in the video have a rather holistic view on the teaching situation (meaning that they notice relevant aspects for student learning even if their attention is not directly alerted to it). Other categories such as "Manageability of didactic material" are an interpretative result of what was visually presented in the video but are not directly observable. In the video, one girl is shown who presents her solution to the teacher. She uses the material that the teacher offers to demonstrate her solution approach. However, she does not try to turn and rotate the Pentominoes which she already found and, therefore, the teachers whose answers belong to this category interpret the manageability of the material without seeing the student actually struggling to flip and rotate the figures.

Here, we can distinguish between categories that are perceived based on directly observable aspects in the teaching sequence and categories that result from interpreting processes. Then again, we can distinguish whether the aspects that are directly observable in the teaching scene are part of the action and, therefore, teachers' attention is directly drawn on them, or whether the aspects are observable in the background. As suggested by expertise research, novice teachers more often perceive surface characteristics in a teaching sequence while expert teachers distinguish important and less important information and interpret the situation deeply and profound (cf. Berliner 2001). In this regard, novice teachers may preferably name categories that are directly observable and part of the main action while expert teachers more often name categories that result from interpreting processes.

In addition, the categories presented above can be classified with regard to their chosen perspective. While some teachers name more mathematics didactical aspects (such as the didactical material in the category "Manageability of didactical material" or the building instruction of Pentominoes in the category "At least two sides are touching") other teachers focus on rather general pedagogical aspects (such as the mode of classroom interaction chosen by the teacher in the categories "Lack of student-to-student interaction" or the teacher's decision about the amount of student participation in the category "Missing students activities"). Here, the categories do not refer as much to the 
mathematical basis of student's mistake but conclude that specific (missing) aspects of the lesson's design may have caused the girl's errors. These classifications of categories are presented in table 2 .

\begin{tabular}{|c|c|c|c|c|}
\hline $\begin{array}{c}\text { Category name and } \\
\text { description }\end{array}$ & $\begin{array}{l}\text { Observability } \\
\text { in the video }\end{array}$ & $\begin{array}{l}\text { Number of } \\
\text { occurrences }\end{array}$ & Perspective & $\begin{array}{l}\text { Number of } \\
\text { occurrences }\end{array}$ \\
\hline $\begin{array}{l}\text { The teacher's } \\
\text { example in the } \\
\text { introduction }\end{array}$ & \multirow{3}{*}{$\begin{array}{c}\text { Observable } \\
\text { and part of the } \\
\text { main action }\end{array}$} & \multirow{3}{*}{66} & \multirow{11}{*}{$\begin{array}{c}\text { Mathematics didactical } \\
\text { aspects }\end{array}$} & \multirow{11}{*}{235} \\
\hline $\begin{array}{c}\text { At least two sides are } \\
\text { touching }\end{array}$ & & & & \\
\hline $\begin{array}{c}\text { More than five } \\
\text { squares as working } \\
\text { material }\end{array}$ & & & & \\
\hline $\begin{array}{l}\text { Pentomino examples } \\
\text { on the poster }\end{array}$ & $\begin{array}{l}\text { Observable } \\
\text { but not part of } \\
\text { the main } \\
\text { action }\end{array}$ & 11 & & \\
\hline $\begin{array}{l}\text { Missing clarification } \\
\text { of preceding figures }\end{array}$ & \multirow{7}{*}{$\begin{array}{c}\text { Not } \\
\text { observable } \\
\text { and not part } \\
\text { of the main } \\
\text { plot }\end{array}$} & \multirow{7}{*}{158} & & \\
\hline $\begin{array}{c}\text { Missing visual } \\
\text { example and/or } \\
\text { counterexample }\end{array}$ & & & & \\
\hline $\begin{array}{l}\text { Manageability of } \\
\text { didactic material }\end{array}$ & & & & \\
\hline $\begin{array}{l}\text { Pentominoes consist } \\
\text { of five squares }\end{array}$ & & & & \\
\hline Pentominoes' name & & & & \\
\hline $\begin{array}{c}\text { The abstract } \\
\text { teacher's description }\end{array}$ & & & & \\
\hline $\begin{array}{c}\text { Incomprehension of } \\
\text { congruence }\end{array}$ & & & & \\
\hline $\begin{array}{l}\text { Color highlighting } \\
\text { the Pentomino } \\
\text { examples }\end{array}$ & $\begin{array}{l}\text { Observable } \\
\text { but not part of } \\
\text { the main plot }\end{array}$ & 4 & \multirow[t]{2}{*}{$\begin{array}{c}\text { General pedagogical } \\
\text { aspect }\end{array}$} & \multirow[t]{2}{*}{65} \\
\hline Missing response to & Not & 61 & & \\
\hline
\end{tabular}


Hoth, Kaiser, Döhrmann, , König \& Blömeke

\begin{tabular}{|c|c|c|c|}
\hline students' questions & \multirow{5}{*}{$\begin{array}{l}\text { observable } \\
\text { and not part } \\
\text { of the main } \\
\text { plot }\end{array}$} & & \\
\hline $\begin{array}{l}\text { Lack of student-to- } \\
\text { student interaction }\end{array}$ & & & \\
\hline $\begin{array}{l}\text { Missing student } \\
\text { activities }\end{array}$ & & & \\
\hline $\begin{array}{c}\text { Ensuring students' } \\
\text { comprehension }\end{array}$ & & & \\
\hline Missing motivation & & & \\
\hline $\begin{array}{l}\text { Answer does not } \\
\text { refer to the question }\end{array}$ & & 15 & 15 \\
\hline
\end{tabular}

Table 2: Classification of inductive categories and frequency analysis 
The table shows that there are more categories about aspects that are not directly observable in the video, and this applies to mathematics didactical as well as to general pedagogical ones. These categories are results from interpreting the classroom events. This refers to 12 of the 18 categories. Moreover, 219 of the 300 mentioned aspects (235 mathematics didactical and 65 general pedagogical ones) belong to this classification (73\%). 66 teachers' answers (22\%) refer to aspects that are directly observable in the video and are also part of the main plot. Three categories belong to this classification. Finally, aspects that are observable in the video but not part of the main plot by the teacher or the students belong to the two categories "Color highlighting the Pentomino examples" and "Pentomino examples on the Poster". These categories are mentioned in only 15 of the teachers' answers (5\%).

In order to clarify whether these differences may be related to the teachers' different knowledge bases, table 3 shows the mathematics didactical categories that resulted from the reducing process. For each category, the table shows the average estimate of the MCK (Mathematics Content Knowledge) and MPCK (Mathematics Pedagogical Content Knowledge) scores of all teachers who mentioned that category in their answer. Table 4 shows that connection between general pedagogical categories and teachers' average estimate of the MPCK and GPK (General Pedagogical Knowledge). The following analysis aims at identifying connections between teachers' noticing (in this case represented by their perception and interpretation) and their professional knowledge. Here, average scores of teachers' knowledge are presented for each of the categories in order to find out whether there are categories (resulting from expert teachers' noticing) that may be mentioned by teachers with higher professional knowledge and vice versa. In table 3 und 4, all average scores are colored light grey that significantly lie above the average score of the entire sample of German primary teachers, dark grey if it significantly lies below.

\begin{tabular}{l|l|l|l|l||l|l|l} 
Categories name & $\begin{array}{l}\text { Observabi } \\
\text { lity }\end{array}$ & $\mathrm{N}$ & $\begin{array}{l}\text { Mean } \\
\text { value } \\
\text { MCK }\end{array}$ & $\begin{array}{l}\text { Standard } \\
\text { deviation }\end{array}$ & N & $\begin{array}{l}\text { Mean } \\
\text { value } \\
\text { MPCK }\end{array}$ & $\begin{array}{l}\text { Standard } \\
\text { deviation }\end{array}$ \\
\hline
\end{tabular} 
Hoth, Kaiser, Döhrmann, , König \& Blömeke

\begin{tabular}{|c|c|c|c|c|c|c|c|}
\hline $\begin{array}{l}\text { The teacher's example in the } \\
\text { introduction }\end{array}$ & \multirow{3}{*}{0} & 38 & $555^{7}$ & 115.1 & 38 & $552^{8}$ & 84.8 \\
\hline At least one side in common & & 12 & 516 & 105.6 & 12 & 518 & 79.1 \\
\hline $\begin{array}{l}\text { More than five squares as } \\
\text { working material }\end{array}$ & & 3 & $514^{9}$ & 46.7 & 3 & $561^{10}$ & 49.4 \\
\hline $\begin{array}{l}\text { Pentomino examples on the } \\
\text { poster }\end{array}$ & 1 & 9 & 533 & 55.6 & 9 & $568^{11}$ & 64.8 \\
\hline $\begin{array}{l}\text { The abstract teacher's } \\
\text { description }\end{array}$ & \multirow{7}{*}{2} & 38 & 550 & 115.4 & 38 & 545 & 95.4 \\
\hline $\begin{array}{l}\text { Missing clarification of } \\
\text { preceding figures }\end{array}$ & & 10 & $572^{12}$ & 79.2 & 10 & $555^{13}$ & 74.8 \\
\hline $\begin{array}{l}\text { Missing visual example and/or } \\
\text { counterexample }\end{array}$ & & 32 & $554^{14}$ & 107.3 & 32 & 538 & 84.2 \\
\hline Manageability of material & & 4 & 538 & 38.3 & 4 & $551^{15}$ & 40.8 \\
\hline $\begin{array}{l}\text { Pentominos consist of five } \\
\text { squares }\end{array}$ & & 4 & $513^{16}$ & 51 & 4 & $581^{17}$ & 45.1 \\
\hline $\begin{array}{l}\text { Incomprehension of } \\
\text { congruence }\end{array}$ & & 38 & $567^{18}$ & 92.3 & 38 & $559^{19}$ & 67.6 \\
\hline Pentominos' name & & 3 & $480^{20}$ & 74.9 & 3 & $486^{21}$ & 24.9 \\
\hline Total & & 214 & 545 & 99.7 & 214 & 544 & 82.4 \\
\hline
\end{tabular}

Table 3: Contingency analysis between the mathematics didactical categories from the inductive codes and teachers' professional knowledge

\footnotetext{
${ }^{7}$ Significant difference with $\mathrm{p}<.05$

${ }^{8}$ Significant difference with $\mathrm{p}<.05$

${ }^{9}$ Significant difference with $\mathrm{p}<.05$

${ }^{10}$ Significant difference with $\mathrm{p}<.005$

${ }^{11}$ Significant difference with $\mathrm{p}<.0005$

${ }^{12}$ Significant difference with $\mathrm{p}<.00005$

${ }^{13}$ Significant difference with $\mathrm{p}<.05$

${ }^{14}$ Significant difference with $\mathrm{p}<.05$

${ }^{15}$ Significant difference with $\mathrm{p}<.05$

${ }^{16}$ Significant difference with $\mathrm{p}<.05$

${ }^{17}$ Significant difference with $\mathrm{p}<.00005$

${ }^{18}$ Significant difference with $\mathrm{p}<.0005$

${ }^{19}$ Significant difference with $\mathrm{p}<.005$

${ }^{20}$ Significant difference with $\mathrm{p}<.00005$

${ }^{21}$ Significant difference with $\mathrm{p}<.00005$
} 
Hoth, Kaiser, Döhrmann, König \& Blömeke

\begin{tabular}{|c|c|c|c|c|c|c|c|}
\hline Categories name & $\begin{array}{l}\text { Observabi } \\
\text { lity }\end{array}$ & $\mathrm{N}$ & $\begin{array}{l}\text { Mean } \\
\text { value } \\
\text { MPCK }\end{array}$ & $\begin{array}{l}\text { Standard } \\
\text { deviation }\end{array}$ & $\mathrm{N}$ & $\begin{array}{l}\text { Mean } \\
\text { value } \\
\text { GPK }\end{array}$ & $\begin{array}{l}\text { Standard } \\
\text { deviation }\end{array}$ \\
\hline $\begin{array}{l}\text { Ensuring students' } \\
\text { comprehension }\end{array}$ & 1 & 14 & 531 & 42.1 & 15 & 651 & 79.1 \\
\hline Missing student activities & \multirow{5}{*}{2} & 15 & 549 & 66.5 & 16 & 637 & 79.1 \\
\hline Missing motivation & & 2 & 523 & 43.6 & 2 & 637 & 47.6 \\
\hline $\begin{array}{l}\text { Missing response to students' } \\
\text { questions }\end{array}$ & & 12 & 519 & 113.4 & 13 & 657 & 75 \\
\hline $\begin{array}{l}\text { Color highlighting the } \\
\text { Pentomino examples }\end{array}$ & & 3 & $576^{22}$ & 71.4 & 4 & $666^{23}$ & 40.2 \\
\hline $\begin{array}{l}\text { Missing student-to-student } \\
\text { interactions }\end{array}$ & & 5 & $462^{24}$ & 126.4 & 4 & $620^{25}$ & 114.7 \\
\hline Total & & 51 & 529 & 82.3 & 54 & 647 & 75.7 \\
\hline
\end{tabular}

Table 4: Contingency analysis between the general pedagogical categories from the inductive codes and teachers' professional knowledge

\footnotetext{
${ }^{22}$ Significant difference with $\mathrm{p}<.0005$

${ }^{23}$ Significant difference with $\mathrm{p}<.05$

${ }^{24}$ Significant difference with $\mathrm{p}<.0005$

${ }^{25}$ Significant difference with $\mathrm{p}<.005$
} 
Table 3 and 4 show that the relation between the categories and the teachers' professional knowledge are very different. Some of the categories that focus on mathematics didactical aspects of the teaching sequence (table 3) were mentioned by teachers with over-average MPCK and MCK ("The teachers example in the introduction", "missing clarification of preceding figures" as well as "Incomprehension of congruency") while other categories were named by teachers with underaverage MPCK and MCK ("Pentomino's name"). With regard to categories that focus on general pedagogical aspects of the teaching sequence (table 4) there was only one category that was named by teachers with above-average knowledge (Color highlighting the Pentomino example) and one category that teachers mentioned who had under-average MPCK and GPK (Missing student-tostudent interaction).

Analyzing the categories that were mentioned by teachers with rather low professional knowledge shows that those categories describe aspects of the teaching sequence that do not directly relate to the student's errors. For example, the awareness of the figures' names ('Pentominoes') does not affect the solution process which is dominated by the missing consideration of congruency and using only one Tetromino as the basis. The girl would be able to find all existing figures if she knows the building requirements of the figures and understands the concept of congruency. However, she does not need to know the name of the figures and this category does not relate to the girl's errors. However, it is true that the teacher introduces the figures and their name only very shortly and does not provide enough time for the student to learn the complex name "Pentomino" or to discover the meaning of it. Therefore, teachers who name this category obviously noticed a specific teaching decision by the teacher that they did not agree with or they would have done differently. However, this category does not explain the girl's errors.

Analyzing the category "Missing student-to-student interaction" results in similar conclusions. It is true that the teacher in the video chose to let the students work for themselves and did not offer opportunities for student-to-student interaction. It is possible that other students did not make the same mistakes as the girl and student-to-student interaction may have resulted in the girl correcting her mistakes due to the interaction. However, this does not provide possible reasons for the girl's errors as inquired by the question. In addition, the other students followed the same introduction as the girl and may be mistaken as well. Again, teachers noticed an element in the teaching situation (the missing group work) that they would probably include into their own teaching. However, this was not linked to the student's understanding.

The categories that teachers with averagely high knowledge facets named have a close connection to the girl's errors. Indeed, the girl does not consider congruency (category "Incomprehension of congruency") and the teacher in the video shows only Pentomino examples that are based on the one specific Tetromino that the girl uses exclusively to construct her figures (categories "The teacher's example in the introduction" and "Examples on the Poster"). In addition, the teacher's organizational decisions that may have caused the error are addressed in the category "Missing clarification of preceding figures". If the teacher discussed the preceding figures in class, this specific error might not have happened. 
Overall, it appears that some categories are not linked to the girl's errors while other categories refer to them closely. Table 3 and 4 showed that for this specific situation, teachers who were able to notice relevant teaching instances and made connections between these specific instances and the girl's learning results often had above-average knowledge. Here, noticing teaching instances as problematic for the understanding and learning of students becomes obvious as one main aspect of teachers' expertise.

In addition to the accuracy of teacher noticing, its complexity and multi-facetted nature may be a characteristic of teachers' expertise. In this regard, the following analyses link the amount of aspects listed by the teachers (as an indication of teachers' wide-ranging perception) and their professional knowledge. Again, the first table shows these relations for the amount of mathematics didactical aspects mentioned by the teachers, table 6 provides that information for the general pedagogical aspects.

\begin{tabular}{l|r|r|r||r|r|r}
$\begin{array}{l}\text { Number of didactical } \\
\text { aspects }\end{array}$ & $\mathrm{N}$ & $\begin{array}{c}\text { Mean value } \\
\text { MCK }\end{array}$ & $\begin{array}{c}\text { Standard } \\
\text { deviation }\end{array}$ & N & $\begin{array}{c}\text { Mean value } \\
\text { MPCK }\end{array}$ & $\begin{array}{c}\text { Standard } \\
\text { deviation }\end{array}$ \\
\hline 0 & 1 & $564^{26}$ & & 1 & $441^{27}$ & \\
\hline 1 & 16 & $509^{28}$ & 128.3 & 16 & $515^{29}$ & 120.9 \\
\hline 2 & 33 & 543 & 73.8 & 33 & 548 & 65.4 \\
\hline 3 & 21 & 547 & 99.3 & 21 & 533 & 92.3 \\
\hline 4 & 9 & 518 & 37.2 & 9 & 536 & 27.5 \\
\hline 5 & 3 & $437^{30}$ & 62.2 & 3 & 534 & 48.3 \\
\hline Total & 83 & 531 & 91.3 & 83 & 535 & 82.5 \\
\hline
\end{tabular}

Table 5: Contingency analysis between the amount of mathematics didactical aspects noticed and the professional knowledge

\footnotetext{
${ }^{26}$ Significant difference with $\mathrm{p}<.005$

${ }^{27}$ Significant difference with $\mathrm{p}<.00005$

${ }^{28}$ Significant difference with $\mathrm{p}<.05$

${ }^{29}$ Significant difference with $\mathrm{p}<.05$

${ }^{30}$ Significant difference with $\mathrm{p}<.00005$
} 
Table 5 shows the relation between the number of didactical aspects that the teachers mentioned and their mean value of MCK and MPCK. This analysis may be a first indication that novice teachers mention only few aspects because teachers who mentioned only one or less didactical aspects have under-average MPCK. Regarding the contingency analysis between the number of pedagogical aspects mentioned by the teachers and their professional knowledge shows that teachers addressing the most pedagogical aspects (in this specific case this amounts to two aspects) have above-average MPCK. This may be a first indication that expert teachers notice a variety of different aspects. However, neither between the number of mathematics didactical aspects and teachers' knowledge scores nor between the number of pedagogical aspects and teachers' knowledge scores were significant correlations found.

Table 6: Contingency analysis between the amount of general pedagogical aspects noticed and the professional knowledge

\section{SUMMARY, DISCUSSION AND CONCLUSIONS}

With the aim to analyze how video as a tool for representing classroom practice can help to investigate aspects of teachers' expertise, the video instrument of the TEDS-Follow-Up study served as an example to analyze what teachers notice and their accuracy in analyzing classroom videos (preciseness meaning in this case to accurately analyze those classroom incidents that may have caused the student's errors). Here, 131 primary mathematics teachers analyzed a student's error that was presented in one of the video vignettes. This specific task was selected for the analyses because it required the teachers to analyze the entire teaching sequence and link specific aspects to the student's understanding. The qualitative analysis resulted in 17 categories that show the plurality of aspects mentioned by the teachers. The aspects that are central in the categories analyzed refer either to objects and incidents that were directly observable in the video and was also part of the main action, while other aspects were observable but not part of the main action and

\begin{tabular}{|c|c|c|c|c|c|c|}
\hline $\begin{array}{l}\text { Number of } \\
\text { pedagogical aspects }\end{array}$ & $\mathrm{N}$ & $\begin{array}{c}\text { Mean value } \\
\text { MPCK }\end{array}$ & $\begin{array}{l}\text { Standard } \\
\text { deviation } \\
\end{array}$ & $\mathrm{N}$ & $\begin{array}{c}\text { Mean value } \\
\text { GPK }\end{array}$ & $\begin{array}{l}\text { Standard } \\
\text { deviation }\end{array}$ \\
\hline 0 & 39 & 549 & 84.2 & 38 & 646 & 95.3 \\
\hline 1 & 31 & $508^{31}$ & 87 & 31 & 652 & 82.2 \\
\hline 2 & 13 & $556^{32}$ & 45.7 & 12 & 638 & 66.9 \\
\hline Total & 83 & 535 & 82.5 & 81 & 647 & 85.9 \\
\hline
\end{tabular}

even other aspects were a result of interpretation processes and were not observable and not part of the main action in the video. Analyses showed that teachers predominately named interpretative categories, the second most often named aspects that were directly observable and part of the main action while aspects that were observable but not part of the main action got addressed the least often. Contingency analyses between the categories and teachers' professional knowledge showed that categories directly linked to the student's errors corresponded with above-average knowledge, while categories that were not the cause of the errors but were weaknesses of the teaching sequence

\footnotetext{
${ }^{31}$ Significant difference with $\mathrm{p}<.005$
}

${ }^{32}$ Significant difference with $\mathrm{p}<.05$ 
shown in the video were connected with below-average knowledge. Finally, a connection between high knowledge and noticing several aspects in the teaching sequence was indicated but could not be proved quantitatively.

The analyses showed that video as a tool for representing practice can offer - to a specific extent the multifaceted happenings that also occur in real classes. The great amount of categories as well as the different perspectives that the teachers choose in their answers provided evidence that teachers noticed very different things in the same (3-minutes!) video while referring to the same question. With regard to teachers' expertise, it became obvious that some teachers noticed crucial aspects for the learning of students while other teachers perceived rather surface characteristics such as the working arrangement in class (individual instead of group work) that are not directly relevant for the students' understanding (cf. Berliner 2001). In addition, and in accordance with the findings with Sabers et al. (1991), the results showed that expert teachers analyzed the reasons for the errors in greater depth - categories that were directly linked to the student's errors were named by teachers with comparatively high knowledge. As Van Es (2011) pointed out, teachers at the lower stages in the Learning to notice framework more often attend only to the teacher's pedagogy without linking it to subject-based reflections. Many of the categories that evolved in the present analyses, also focus on the teacher's pedagogy such as her decision on work arrangement ("Lack of student-tostudent interaction"), her coloring of the Pentominoes ("Color highlighting the Pentomino examples"), her waiver of student activities and answering student questions ("Missing students' activity" and "Missing response to students' questions") or that she did not ensure the student's understanding of the work assignment ("Ensuring students' understanding"). Most of these categories that focused on the teacher's pedagogy were not directly linked to the student's errors because they were not subject-related and, therefore, did not refer to the student's mathematical thinking.

Focusing on the connections between teachers' noticing and their professional knowledge, the findings suggest that high professional knowledge is linked to noticing crucial aspects of student learning. However, and in accordance with findings from other studies (e. g. Dreher \& Kuntze 2015), the results did not indicate that the categories that were more subject-related are linked to high subject-specific knowledge, while categories with a general pedagogical focus are linked to high general pedagogical knowledge. For this specific teaching incidence - analyzing instruction with regard to students' understanding - it showed that teachers with high professional knowledge (subject-specific AND general pedagogical) identified crucial elements while teachers with low professional knowledge focused on elements that they observed and clarified as insufficient but they were not able to relate them to the student's understanding.

However, critically reflecting the video instrument and its potential to assess teachers' professional competencies involves reflecting that the participating teachers analyzed, evaluated and judged a teaching sequence with unknown students. The participating teachers did not have the same background knowledge about the students, their behavior and prior knowledge as they would have had from their own class. Since the videos were cut and scripted, teacher noticing was assessed in very condensed situations. Many significant things happened in a very short time. In addition, teachers' perception was guided by the camera script which may also have had affected the results. As mentioned, the qualitative analysis of the teachers' answers to a specific question concerning 
those videos provided some potential. However, since the teachers were asked to name exactly three instances of the video, interviewing teachers about this specific question, using the video as prompt, might even result in a greater variety of categories.

In total, these different analyses showed that video as a tool for representing practice can help to investigate aspects of teacher expertise, such as noticing crucial aspects of students' learning.

\section{References}

Berliner, D. C. (2001). Learning about and learning from expert teachers. International Journal of Educational Research, 35 (5), 463-482.

Blömeke, S., Gustafsson, J.-E., \& Shavelson, R. (2015). Beyond dichotomies: competence viewed as a continuum. Zeitschrift für Psychologie, 223 , 3-13.

Blömeke, S., Hsieh, F.-J., Kaiser, G., \& Schmidt, W. H. (Eds.). (2014). International perspectives on teacher knowledge, beliefs and opportunities to learn. Dordrecht: Springer.

Blomberg, G., Stürmer, K., \& Seidel, T. (2011). How Pre - Service Teachers Observe Teaching on Video: Effects of Viewers' Teaching Subjects and the Subject of the Video. Teaching and Teacher Education 27 (7),. 1131-1140.

Carter, K., Cushing, K., Sabers, D., Stein, P. \& Berliner, D. C. (1988). Expert-novice differences in perceiving and processing visual information. Journal of Teacher Education, 39, $25-31$.

Chi, M. T.; Feltovich, P. J.; Glaser, R. (1981). Categorization and representation of physics problems by experts and novices. Cognitive Science 5 (2), 121-152.

Dreher, A. \& Kuntze S. (2015). Teachers' professional knowledge and noticing: The case of multiple representations in the mathematics classroom. Educational Studies in Mathematics, 88 (1), 89-114.

Golomb, S. W. (1994). Polyominoes - Puzzles, Patterns, Problems and Packings. Princeton University Press.

Herbst, P., Chazan, D., Kosko, K. W., Dimmel, J. \& Erickson, A. (2015). Using multimedia questionnaires to study influences on the decisions mathematics teachers make in instructional situations. ZDM Mathematics Education, 48(1-2), 167-183.

Hoth, J., Döhrmann, M., Kaiser, G., Busse, A., König, J. \& Blömeke, S. (2016). Diagnostic competence of primary school mathematics teachers during classroom situations. ZDM Mathematics Education, 48(1-2), 41-54.

Hoth, J., Schwarz, B., Kaiser, G., Busse, A., König, J. \& Blömeke, S. (2016). Uncovering predictors of disagreement: Ensuring the quality of expert ratings. ZDM Mathematics Education, 48(1-2), 83-98.

Jacobs, V. R., Lamb, L. L., \& Philipp, R. A. (2010). Professional Noticing of Children's Mathematical Thinking. Journal for Research in Mathematics Education, 2(41), 169-202.

Kaiser, G., Busse, A., Hoth, J., König, J., \& Blömeke, S. (2015). About the complexities of video-based assessments: Theoretical and methodological approaches to overcoming shortcomings of research on teachers' competence. International Journal of Science and Mathematics Education, 13(2), 369-387.

Kersting, N. (2008). Using video clips of mathematics classroom instruction as item prompts to measure teachers knowledge of teaching mathematics. Educational and Psychological Measurement, 68, 845-861.

Kersting, N. B., Givvin, K., Sotelo, F., \& Stigler, J. W. (2010). Teacher's Analysis of Classroom Video Predicts Student Learning of Mathematics: Further Explorations of a Novel Measure of Teacher Knowledge. Journal of Teacher Education, 61, No. 1-2, 172-181 . 
Kersting, N.B., Givvin, K.B., Thompson, B.J., Santagata, R., \& Stigler, J.W. (2012). Measuring Usable Knowledge: Teachers' Analyses of Mathematics Classroom Videos Predict Teaching Quality and Student Learning. American Educational Research Journal, 49(3), 568-589.

König, J., S. Blömeke, P. Klein, U. Suhl, A. Busse, \& G. Kaiser (2014). Is Teachers' General Pedagogical Knowledge a Premise for Noticing and Interpreting Classroom Situations? A Video-based Assessment Approach. Teaching and Teacher Education 38: 76-88.

König, J., \& C. Kramer (2016). "Teacher Professional Knowledge and Classroom Management: On the Relation of General Pedagogical Knowledge (GPK) and Classroom Management Expertise (CME)." ZDM Mathematics Education 48 (1-2): 139-151.

Kuckartz, U. (2014). Qualitative text analysis. A guide to methods, practice and using software. London: Sage Publications.

Kunter, M., Baumert, J., Blum, W., Klusmann, U., Krauss, S., \& Neubrand, M. (Eds.). (2011). Professionelle Kompetenz von Lehrkräften: Ergebnisse des Forschungsprogramms COACTIV. Münster: Waxmann.

Livingston, C., \& Borko, H. (1989). Expert and novice differences in teaching: A cognitive analysis and implications for teacher education. Journal of Teacher Education, 40 , 36-42.

Mayring, P. (2015). Qualitative content analysis: theoretical background and procedures. In A. Bikner Ahsbahs, C. Knipping, \& N. Presmeg (Eds.), Approaches to qualitative research in mathematics education. Examples of methodology and methods (p. 365-380). Dordrecht: Springer.

Sabers, D.S., Cushing, K.S.., \& Berliner, D.C. (1991). Differences among teachers in a task characterized by simultaneity, multidimensionality, and immediacy. American Educational Research Journal, 28, 63-88.

Schäfer, S., Seidel, T. (2015). Noticing and reasoning of teaching and learning components by pre-service teachers. In: Journal for educational research online, 7 (2), 34-58

Schmidt, W. H., Blömeke, S. \& Tatto, M. T. (2011). Teacher Education Matters: A Study of The Mathematics Teacher Preparation from Six Countries. New York: Teacher College Press.

Sherin, M. G.; Jacobs, V. R.; Philipp, R. A. (2011a) (Eds.) Mathematics teacher noticing: Seeing through teachers' eyes. New York: Taylor and Francis.

Sherin, M. G., Jacobs, V. R. \& Philipp, R. A. (2011b). Situating the Study of Teacher Noticing. In Sherin M. G., Jacobs, V. R., \& Philipp, R. A. (Eds.). Mathematics Teacher Noticing. Seeing Through Teachers' Eyes (p.3-13). New York: Routledge.

Shulman, L. S. (1986). Those Who Understand: Knowledge Growth in Teaching. Educational Researcher, $15(2), 4-14$.

Shulman, L. S. (1987). Knowledge and Teaching: Foundations of the New Reform. Harvard Educational Review, 57 (1), 1-22.

Star, J. R. \& Strickland, S. K. (2008). Learning to observe: Using video to improve preservice mathematics teachers' ability to notice. Journal of Mathematics Teacher Education, 11(2), 107-125.

Star, J. R., Lynch, K., \& Perova, N. (2011). Using video to improve mathematics teachers' abilities to attend to classroom features: A replication study. In M. Sherin, V. Jacobs, \& R. Philipp (Eds.), Mathematics teachers' noticing: Seeing through teachers' eyes. (p. 117-133) New York: Routledge.

Tatto, M.T., Schwille, J., Senk, S.L., Ingvarson, L., Rowley, G., Peck, R., Bankov, K., Rodriguez, M., \& Reckase, M. (2012). Policy, practice, and readiness to teach primary and secondary mathematics in 17 countries: Findings from the IEA Teacher Education and Development Study in Mathematics (TEDS-M). Amsterdam: IEA.

Van Es, E. A., \& Sherin,M. G. (2002). Learning to notice: Scaffolding new teachers' interpretations of classroom interactions. Journal of Technology and Teacher Education, 10(4), 571-596. 
Hoth, Kaiser, Döhrmann, , König \& Blömeke

Van Es, E. A. (2011). A framework for Learning to Notice Student Thinking. In Sherin, M. G., Jacobs, V. R. \& Philipp, R. A. (Eds.), Mathematics teacher noticing: Seeing through teachers' eyes (p. 134-151). New York, NY: Routledge. 